\title{
Polymorphism of Plasmodium Falciparum Dihydrofolate Reductase and Dihydropteroate Synthase Genes among Pregnant Women with Falciparum Malaria in Banjar District, South Kalimantan Province, Indonesia
}

\author{
Fitriah $^{1}$, Sri Wijayanti Sulistyawati1 ${ }^{1,2}$, Sugeng Riyanto ${ }^{3}$, Budiono $^{4}$, Sukmawati Basuki ${ }^{1,2 *}$, \\ Yoes Prijatna Dachlan ${ }^{2,5}$, Haruki Uemura ${ }^{6}$ \\ ${ }^{1}$ Laboratory of Malaria, Institute of Tropical Disease, Airlangga University, Kampus C Jl. Mulyorejo Surabaya 60115, Indonesia \\ ${ }^{2}$ Department of Medical Parasitology, Faculty of Medicine, Airlangga University, Surabaya 60131, Indonesia \\ ${ }^{3}$ Department of Health of Banjar District, South Kalimantan Province, Indonesia \\ ${ }^{4}$ Department of Public Health and Preventive Medicine, Faculty of Medicine, Airlangga University, Surabaya 60131, Indonesia \\ ${ }^{5}$ Tropical Infectious Diseases Hospital, Kampus C Airlangga University, Surabaya 60115, Indonesia \\ ${ }^{6}$ Department of Protozoology, Institute of Tropical Medicine, Nagasaki University, Nagasaki 852-8523, Japan
}

\section{ABSTRACT}

Pregnant women are highly vulnerable to malaria infection in its endemic areas, particularly infection by Plasmodium falciparum that can cause premature, low birth weight, severe anemia in pregnant women, and death. Sulfadoxine-pyrimethamine (SP) for Intermittent Preventive Treatment for pregnant (IPTp) is used for malaria control in pregnancy recommended by the World Health Organization that has already been implemented in Africa. The $P$. falciparum resistance to SP has been reported in several malarial endemic areas, and mutations in the genes of Plasmodium falciparum Dihydrofolate Reductase (Pfdhfr) and Dihydropteroate Synthase (Pfdhps) are shown to be associated with parasite resistance to SP treatment. Genetic analysis of Pfdhfr and Pfdhps genes in pregnant women infected with $P$. falciparum has not yet been examined in Indonesia. The cross-sectional study was conducted at two subdistricts, Sungai Pinang and Peramasan, in Banjar district of South Kalimantan Province, where 127 pregnant women were recruited from 2008 to April 2010. Two important mutations in Pfdhfr gene (amino acid positions at N51 and S108) and three in Pfdhps gene (A437, K540 and A581) were analyzed by nested PCR-RFLP method. All of the seven pregnant women samples infected with P. falciparum presented PfDHFR 108N and PfDHPS 437G mutations. One of the samples had the additional mutation at PfDHPS 540, in which Lys is substituted by Glu. These results suggested that $P$. falciparum might present only some resistance to SP at Sungai Pinang and Peramasan subdistricts, Banjar District, South Kalimantan province, Indonesia. Although there were limited number of samples, this study showed only few mutations of Pfdhfr and Pfdhps genes in $P$. falciparum at Banjar district, South Kalimantan Province, that suggests SP might be effective for IPTp in this area. Thus, further analysis of the other mutation sites in Pfdhfr and Pfdhps genes and in vivo efficacy study of SP with more sufficient sample numbers will be necessary to confirm this preliminarily result.

Keywords: Pfdhfr, Pfdhps, Pregnant women, Falciparum malaria

\section{BACKGROUND}

Pregnant women in malaria endemic areas are highly vulnerable to malaria infection, particularly Plasmodium falciparum (P. falciparum) infection that can cause prematurity, low birth weight (LBW), severe anemia and death. Complications are more common in the Primi-

*Corresponding Address:

Sukmawati Basuki

Department of Medical Parasitology,

Faculty of Medicine, Airlangga University,

Jl. Mayjen Prof Dr. Moestopo 47, Surabaya 60131

Phone : +62 31-520251-2 Fax : +62 31-5013749,

E-mail : sukmabas@yahoo.com gravidae than multigravidae [1-3]. As a consequence of the impact of malaria on pregnancy, malaria control during pregnancy requires the highest attention and carefulness. World Health Organization (WHO) has recommended the use of sulphadoxinepyrimethamine (SP) for intermittent preventive treatment (IPT) for malaria control in pregnancy. This policy has been implemented in Africa [4]. SP has been proven safe for the second and third trimester of pregnancy. It has an affordable price, is widely available, needs a single dose treatment and is effective in reducing the risk of LBW and placental malaria [5-7]. 
However, the level of resistance to SP has increased and rapidly spread due to the parasite's ability to perform gene mutation as a response to drug pressure, that is, the occurrence of point mutations in genes that are targeted by the drug [8]. Monitoring molecular markers of SP resistance is very valuable to determine drug policy for the prevention and treatment of malaria in pregnancy [9]. Mutations in PfDHFR and PfDHPS genes are associated with resistance of $P$. falciparum to SP. Key mutations of resistance to pyrimethamine is PfDHFR gene mutation at codon 108 which has been a change $\mathrm{Ser} \rightarrow \mathrm{Asn}$ or Ser $\rightarrow \mathrm{Thr}$, and point mutations in three other codons of $51 \quad$ [Asn $\rightarrow$ Ile], 59 [Cys $\rightarrow$ Arg], and 164 [Ile $\rightarrow$ Leu]. Mutations in PfDHPS associated with resistance to sulfadoxine is $\mathrm{Ser} \rightarrow \mathrm{Ala}$ or $\mathrm{Ser} \rightarrow \mathrm{Phe}$ at codon 436, Ala $\rightarrow$ Gly at codon 437, Lys $\rightarrow$ Glu at codon 540, Ala $\rightarrow$ Gly at codon 581, Ala $\rightarrow \mathrm{Thr}$ or $\mathrm{Ala} \rightarrow \mathrm{Ser}$ at codon 613[10-19]. The presence of mutations at codons 437 and 540 of PfDHPS together with the triple mutation of PfDHFR [quintuple mutation] is a significant predictor of SP treatment failure [20].

In Indonesia, SP had been used as an alternative malaria drug since 1999 [21] and was still used in Banjar district until 2009 [22]. The first cases of SP resistance in Indonesia were encountered in 1979 [23], followed by their occurences in several provinces of Indonesia [2426]. Research on the effectiveness of SP in association with mutations of genes coding for PfDHFR and PfDHPS in several malarial endemic areas and also in pregnant women in several malarial endemic areas in Africa have been conducted [24-29]. Therefore, World Health Organization released the recommendation of a threshold of a parasite genetic marker of SP-resistance $50 \%$ prevalence of the pfdhps 540) above which SP-IPTp is not recommended for use in Africa [30]. However, no information is available in particular for pregnant women infected with $P$. falciparum in malaria endemic areas in Indonesia. This study aims to determine the mutations of Pfdhfr and Pfdhps genes in pregnant women infected with $P$. falciparum at Peramasan and Sei Pinang subdistricts, Banjar District, South Kalimantan Province, that belong to malaria endemic areas.

\section{MATERIALS AND METHODS}

\section{Study sites}

The study was carried out at two subdistricts, Sungai Pinang and Peramasan, in Banjar district, South Kalimantan Province. The topography of
Peramasan subdistrict is mountainous and surrounded by dense forests and shrubs, with small rivers in between meetings of the mountain [see Figure 1]. The population was 3,730 inhabitants in which most people work as farmers and traditional gold miners. Sungai Pinang is an area of rolling hills scattered in mountainous areas Meratus in which some villages belong to remote areas. The population was 16,245 inhabitants in 2008 in which most of people work as farmers. The most common vectors are Anopheles balabacensis, Anopheles maculatus, Anopheles letifer, Anopheles umbrosus, Anopheles kochi, Anopheles nigerrimus, and Anopheles vanu [22].

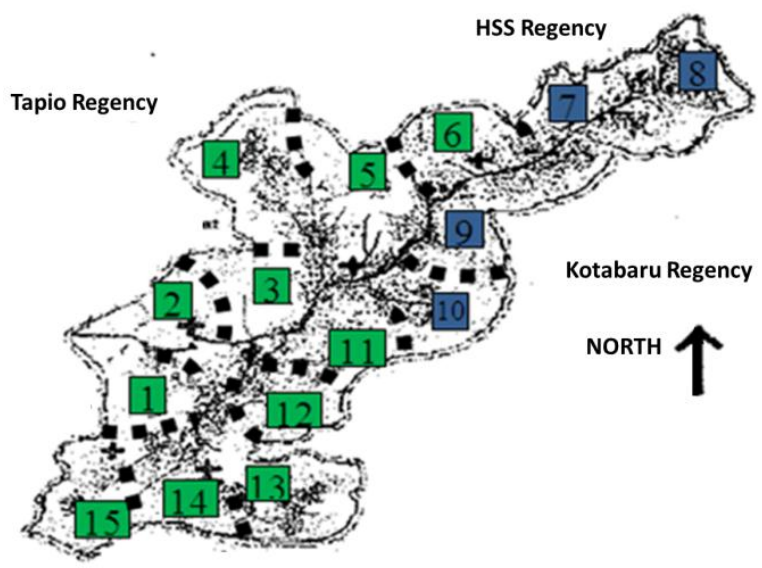

Figure 1. Sampling positions at Sungai Pinang (green) and Peramasan sub districts (blue). 1. Kupang Rejo village; 2. Sungai Pinang; 3. Pakutik; 4. Rantau Nangka; 5. Rantau Bakula; 6. Belimbing Baru; 7. Peramasan Atas; 8. Peramasan Bawah; 9. Remo; 10. Angkipih; 11. Belimbing Lama; 12. Sumber Baru; 13. Sumber Harapan; 14. Kahela'an; 15. Hakim Makmur

\section{Participants}

The cross-sectional study was conducted. Pregnant women presenting for routine antenatal care at Sungai Pinang and Peramasan Health Centres were recruited from 2008 to April 2010. The study protocol was reviewed and approved by the Ethics Committee of Medical Research, Faculty of Medicine, Airlangga University, Surabaya, No. 26 /EC / KEPK /FKUA /2010. Informed consent was obtained from all participants.

\section{Species Identification}

Malaria screening used Giemsa stained thin and thick blood smears under microscopy by local staffs. Blood samples for the molecular analysis were collected on filter paper (Advantec, Toyo Roshi Kaisha, Ltd., Japan). Malaria parasite densities were counted per 200 white blood cells (WBC) on Giemsa stained thin and thick smears, 
calculated as parasites per microliter. Submicroscopic plasmodial infections and parasite species were assessed by nested polymerase chain reaction (PCR) assays after extraction of DNA from filter paper (QIAmp Blood Kit, Qiagen, Hilden, Germany).

\section{Detection of the PfDHFR and PfDHPS mutations.}

We analyzed two point mutations in the Pfdhfr gene (51 and 108) and three point mutations in the Pfdhps gene (437, 540 and 581). The detection of mutations in Pfdhfr and Pfdhps was carried out by using nested PCR followed by restriction fragment length polymorphism (RFLP) [31-32]. The first-round PCR amplification was performed in a $20 \mu \mathrm{l}$ mixture containing $2 \mu \mathrm{l}$ of DNA sample, $200 \mu \mathrm{M}$ dNTP, $0.4 \mu \mathrm{M}$ of each primer, as described by previouse report [33], and $1 \mathrm{U}$ Taq polymerase (Takara Ltd, Japan). Nested PCR was performed in a $15 \mu$ mixture containing $2 \mu \mathrm{l}$ of the first PCR product with $10 \mathrm{X}$ dilution. RFLP was performed by administering the enzyme digestion at optimum temperature and time required as in the brochure from the manufacturer. Five microliters of nested PCR products were used without purification in the total volume of $50 \mu \mathrm{l}$ containing $5 \mathrm{U} / \mu \mathrm{l}$ enzyme digestion, $5 \mu \mathrm{l}$ buffer, $5 \mu \mathrm{BSA}$ and $30 \mu \mathrm{l}$ distilled water. The digestion products were detected by ethidium bromide stained 2\% agarose gel under UV light after electrophoresis. For the Pfdhfr mutations, AluI cut only the wild-type gene (S108), BsrI cut only the mutant gene $(108 \mathrm{~N})$ and $\operatorname{ScrFI}$ cut only the mutant gene (108T). Tsp509I only cut the wildtype gene (51I). For the Pfdhps mutations, AvaII cut only the mutant gene (437G), FokI cut only the mutant gene $(540 \mathrm{E})$ and $B s t \mathrm{UI}$ cut only the mutant gene $(581 \mathrm{G})$. For each series of samples, water was used as a negative control. For the detection of 108N, 3D7-DNA was used as the wild-type control, K1-DNA was used as the mutant control of $108 \mathrm{~N}$, and FCR3-DNA was used as the mutant control of 108T. For the detection of $437 \mathrm{G}$, FCR3-DNA was used as the wild-type control, while 3D7 and K1-DNA were used as the mutant control of $437 \mathrm{G}$.

\section{RESULT AND DISCUSSION}

\section{Subject Characteristics}

Total 127 pregnant women were involved in this study, consisting of 30 pregnant women from Peramasan Health Centre and 97 pregnant women from Sungai Pinang Health Centre (HC). Most of the pregnant women aged between 2030 years, $60 \%$ in Peramasan HC and $54 \%$ in Sei Pinang HC. They represented mostly at the first pregnancy (primigravida) compared with at the second pregnancy and the third or more pregnancy, 13 [43\%] in Peramasan HC and 48 $[49 \%]$ in Sei Pinang HC.

\section{Species Identification}

In Peramasan HC, malaria screening resulted in 10 pregnant women infected with Plasmodium, while 13 pregnant women were infected with Plasmodium in Sungai Pinang HC. The species identification by nested PCR resulted in 12 malaria cases among these pregnant women, 6 pregnant women with malaria occurred in each health centre. The identification of malaria parasites infected to pregnant women was shown in Table 1. The pregnant women with malaria were manifested in the fever that appeared as a dominant malarial symptom.

\section{Mutations of PfDHFR and PfDHPS Genes}

Six of seven samples pregnant women with malaria falciparum had the double mutation which consisted of PfDHFR 108N mutation and the single mutation of PfDHPS gene 437G. One sample had the triple mutations which consisted of $108 \mathrm{~N}$ mutation in pfdhfr gene and the double mutation of PfDHPS (437G and 540E). The 51I and 108T mutations in the Pfdhfr gene and the $581 \mathrm{G}$ mutation in the Pfdhps gene were not observed in this study (see table 2).

We found two types of PfDHFR, PfDHPS mutants in seven $P$ falciparum isolates in Banjar district, particularly in Sei Pinang and Peramasan subdistricts. All isolates, except one, contained the PfDHFR 108N/PfDHPS 437G double mutant. One isolation contained the PfDHFR 108N/PfDHPS 437G/540E triple mutant. Recently, PfDHPS 540E mutant has been demonstrated as a predictor for $P$. falciparum resistance to SP. When PfDHPS 540E mutant was joined together with the triple mutation of PfDHFR as the quintuple mutation, it indicates a significant predictor of SP treatment failure. Below 50\% prevalence of the PfDHFR 540 mutation is used as a threshold of a parasite genetic marker of SP-resistance, in the program of Intermittent Preventive Treatment (IPT) during infancy in Africa $[20,30,34,35]$. One isolate containing PfDHPS 540E mutant found in our study with the mutation of PfDHFR $108 \mathrm{~N}$ and mutation of PfDHPS $437 \mathrm{G}$ as the triple 
mutations. The other six isolates presented the wild type K540 PfDHPS, and it suggested parasites might be quite sensitive to SP treatment. However, further studies with sufficient numbers of samples are required for finding out the appropriate prevalence of PfDHPS 540E mutant in order to provide the recommendation for SP-IPTp implementation in Indonesia. Moreover, one needs to clarify the other point mutations in association to SP resistance by in vivo study for efficacy of SP combined with the analysis of molecular marker of SP resistance.

Table 1. The determintaion of malaria parasites in pregnant women with malaria

\begin{tabular}{|c|c|c|c|c|c|c|}
\hline \multirow[t]{2}{*}{ Health Centre } & \multicolumn{3}{|c|}{ Microscopy* } & & \multicolumn{2}{|c|}{ Nested PCR } \\
\hline & $\overline{\mathrm{Pf}}$ & $\mathrm{PV}_{\mathrm{V}}$ & Mix $\mathrm{Pf}$ and $\mathrm{Pv}$ & $\mathrm{Pf}$ & $\mathrm{PV}_{\mathrm{V}}$ & Mix Pf and $\mathrm{Pv}$ \\
\hline Sungai Pinang & 1 & 5 & 4 & 1 & 3 & 2 \\
\hline Peramasan & 3 & 6 & 4 & 3 & 2 & 1 \\
\hline
\end{tabular}

* Malaria screening used Giemsa stained thin and thick blood smear under microscopy.

Pf: P. falciparum, Pv: P. Vivax; Mix Pf and Pv: mixed infection of Pf and Pv

Table 2. PfDHFR and PfDHPS gene mutations, and density of parasites / ul blood sample in pregnant women infected with P. falciparum in Sungai Pinang and Peramasan Health Centers

\begin{tabular}{|c|c|c|c|c|c|c|c|c|}
\hline \multirow{3}{*}{ Sample } & \multirow{2}{*}{\multicolumn{3}{|c|}{ Microscopy }} & \multicolumn{5}{|c|}{ Nested PCR-RFLP } \\
\hline & & & & \multicolumn{2}{|c|}{ PfDHFR } & \multicolumn{3}{|c|}{ PfDHPS } \\
\hline & $\mathrm{Pf}$ & Mix $\mathrm{Pf}$ and $\mathrm{Pv}$ & density of parasites / ul & 51 & 108 & 437 & 540 & 581 \\
\hline KH1 & $\overline{\mathrm{Pf}}$ & & 35405 & asn & asn & gly & lys & ala \\
\hline KH6* & & mix & 33742 & asn & asn & gly & lys & ala \\
\hline KH9 & & $\operatorname{mix}$ & 320 & asn & asn & gly & glu & ala \\
\hline KH14* & Pf & & 45962 & asn & asn & gly & lys & ala \\
\hline KH16* & & mix & 4815 & asn & asn & gly & lys & ala \\
\hline KH17 & Pf & & 2395 & asn & asn & gly & lys & ala \\
\hline KH23 & Pf & & 6834 & asn & asn & gly & lys & ala \\
\hline
\end{tabular}

Pinang health center

There were two types of isolates containing PfDHFR and PfDHPS mutants in Peramasan subdistrict. In fact, the people's mobilization was high in here due to the development of social and economy, i.e. mining in the forest, plantations and agricultural industries. The workers in mining and forestry are seasonal and come not only from South Kalimantan but also from various regions in Indonesia, including Java and Papua that belong to malaria endemic areas $[22,36]$. So, there is a great chance for the spread of PfDHFR and PfDHPS mutants from other malaria endemic areas such as Java or Papua. Whereas in Sungai Pinang subdistrict, there was one type of isolations containing PfDHFR and PfDHPS mutants (PfDHFR 108N/PfDHPS $437 \mathrm{G})$. The people's mobilization in here was low. However, the limited isolations found in Sungai Pinang were not easy to illustrate this matter.

Based on the previous studies in Indonesia and its neighboring countries, the pattern of mutations of PfDHFR and PfDHPS genes in isolations was various. For instance, in Purworejo, Central Java, there was found a single mutation of PfDHFR gene $108 \mathrm{~N} / 108 \mathrm{~T}$ or paired with 59R/164L and a single mutation of PfDHPS gene $437 \mathrm{G}$ or paired with the 540E. In Sumba and Timor Leste, there was obtained the $108 \mathrm{~N}$ and 51I double mutations in Pfdhfr gene and a single 437G mutation in Pfdhps gene [3639]. In Papua New Guinea, there was found the gene mutation $108 \mathrm{~N}$ and $59 \mathrm{R}$ and single mutation PfDHPS $437 \mathrm{G}$ or paired with the $540 \mathrm{E}[38,41]$. Our study analyzed only two codons of 51 and 108 in Pfdhfr gene and detected mutation at 108 only, while 5 . the other possible mutation at 59 has been reported in Indonesia and Southeast Asia [42]. So, it is possible that the mutations of PfDHFR gene in pregnant women with falciparum malaria who live in Sungai Pinang and Peramasan may not only carry the one mutation but also may carry the other mutations, including the mutation in codon of 59 and of 164. This codon needs to be analyzed in further study, whereabout the presence of triple mutations of PfDHFR together with two mutations of PfDHPS (437G and $540 \mathrm{E}$ ) could be the predictor for SP resistance $[20,30]$. 
Pregnant women with malaria having no willing to participate and no visiting $\mathrm{HC}$ due to their homes in remote areas might cause the limited isolations in our study. On the other hands, the prevalence of malaria in pregnant women was $35.7 \%$ in three months under active detection by Riyanto [36], 12.8\% under passive detection at the two health centers in the study sites, and most people living in these areas $(83.3 \%)$ used bed-nets in 2008 under research observation by WHO (unpublished). There is a good road now with a public transportation from HC to a district hospital, which creates an ease for for people movements. These environmental situation change might have influenced to our study of limited number of sample isolations.

Even though limited number of malaria infected pregnant women could be recruited and some of the important mutation sites were analyzed in this preliminary study yet, we could provide a basic important information and necessity of further malaria drug resistance information to guide drug policy on the prevention and treatment of malaria in pregnancy.

\section{CONCLUSION}

Although there was limited number of samples, this study shows only a few mutations of PfDHFR and PfDHPS gene in P. falciparum at Banjar district, South Kalimantan Province, that suggests SP might be effective for IPTp resistance to $\mathrm{SP}$ at this area. Thus, further analysis of the other mutation sites in Pfdhfr and Pfdhps genes and in vivo efficacy study of SP with more sufficient sample numbers will be necessary to confirm this preliminarily result. Therefore, further research is needed with a lot of isolations for the sake of 1] clarifying more the point of mutation in relation to SP resistance by in vivo study for efficacy of SP combined with analysis of molecular marker of SP resistance, 2] finding out the appropriate prevalence of PfDHPS 540 mutant, and 3] finding out the predictive value of the PfDHFR and PfDHPS mutations for IPT with SP.

\section{ACKNOWLEDGEMENTS}

The authors gratefully acknowledge the Health Organs and staffs in South Kalimantan Province, particularly Sei Pinang Health Centre and Peramasan Health Centre, and WHO grant for invaluable input and encouragement.

\section{REFERENCES}

1. Luxemburger C, McGready R, Kham A, Morison L, Cho T, Chongsuphajaisiddhi T, White NJ \& Nosten F (2001) Effects of Malaria during Pregnancy on Infant Mortality in an Area of Low Malaria Transmission. A J Epidemiol. 154 (5) : 459-465

2. Shulman CE \& Dorman EK (2003) Reducing childhood mortality in poor countries Importance and prevention of malaria in pregnancy. Transactions of the Royal society of Trop. Med. Hyg. 97: 30- 35

3. Menendez C, Alessandro UD \& Kuile FO (2007) Reducing the burden of malaria in pregnancy by preventive strategies. Lancet Infect Dis. 7: 12635

4. Yartey JE (2006) Malaria in pregnancy: Access to effective interventions in Africa. International Journal of Gynecology and Obstetrics. 94: 364373

5. Rogerson SJ, Chahaluka E, Kaujala M, Mkundika P, Mhango C \& Molyueux ME (2000) Intermittent sulfadoxine-pyrimethamine in pregnancy: effectiveness against malaria morbidity in Blantyre, Malawi, in 1997-99. Transactions of the Royal society of Tropical Medicine and Hygiene. 94: 49-553

6. Newman RD, Parise ME, Slutsker L, Nahlen B \& Steketee RW (2003) Safety, efficacy and determinants of effectiveness of antimalarial drugs during pregnancy: implications for prevention programmes in Plasmodium falciparum-endemic sub-Saharan Africa. Tropical Medicine and International Health. 8 (6): 488506

7. Sirima SB, Cotte AH, Konate A, Moran AC, Asamoa K, Bougouma EC, Diarra A, Ouedraogo A, Parise ME \& Newman RD (2006) Malaria prevention during pregnancy : assessing the disease burden one year after implementing a program of intermitten preventive treatment in Koupela District, Burkina Faso. Am. J. Trop. Med. Hyg. 75(2): 205-211

8. Plowe CV (2001) Folate antagonists and mechanisms of resistance. In : Rosenthal PJ. Antimalarial chemotherapy, mechanisms of action, resistance, and new directions in drug discovery. Totowa, New Jersey : Humana Press Inc, pp 173-186.

9. Mockenhaupt FP, Bedu-Addo G, Junge C, Hommerich L, Eggelte TA \& Bienzle U (2007) Markers of sulfadoxine-pyrimethamine-resistant Plasmodium falciparum in placenta and circulation of pregnant women. Antimicrob Agents Chemother. 51(1):332-334.

10. Trigilia T, Menting JGT, Wilson C \& Cowman AF (1997) Mutations in dihydropteroate synthase are responsible for sulfone and sulfonamide resistance in Plasmodium falciparum. Proc. Natl. Acad. Sci. USA. 94: 13944-13949 
11. Wang P, Lee C, Bayoumi R, Djimde A, Doumbo O, Swedberg G, Dao LD, Mshinda H, Tanner M, Watkins WM, Sims PFG \& Hyde JE (1997) Resistance to antifolates in Plasmodium falciparum monitored by sequence analysis of dihydropteroate synthetase and dihydrofolate reductase alleles in a large number of field samples of diverse origins. Molecular and Biochemical Parasitology. 89 : 161-177

12. Biswas S, Escalante A, Chaiyaroj S, Angkasekwinai P \& Lai AA (2000) Prevalence of point mutations in the dihydrofolate reductase and dihydropteroate synthetase genes of Plasmodium falciparum isolates from India and Thailand: a molecular epidemiologic study. Trop. Med. Int. Health. 5 (10): 737-743

13. Happi CT, Gbotosho GO, Folarin OA, Akinboye DO, Yusuf BO, Ebongb OO, Sowunmia A, Kyle DE, MilhousW, Wirth DF \& Oduola AMJ (2005) Polymorphisms in Plasmodium falciparum dhfr and dhps genes and age related in vivo sulfadoxine-pyrimethamine resistance in malariainfected patients from Nigeria. Acta Tropica. 95 : 183-193

14. Ndiaye D, Daily JP, Sarr O, Ndir O, Gaye O, Mboup S \& Wirth DF (2005) Mutations in Plasmodium falciparum dihydrofolate reductase and dihydropteroate synthase genes in Senegal. Trop Med Int Health 10 (11) : 1176-1179

15. Tarimo DS (2005) Emergence of mutations associated with resistance to SulfadoxinePyrimethamine (SP) after single therapeutic dose: implications on the useful therapeutic life of SP in malaria holoendemic areas. East African Journal of Public Health. 2 : 28-31

16. Fernandes N, Figueiredo P, E do Rosário V \& Cravo P (2007) Analysis of sulphadoxine/ pyrimethamine resistance-conferring mutations of Plasmodium falciparum from Mozambique reveals the absence of the dihydrofolate reductase 164L mutant. Malaria Journal. 6:35.

17. Figueiredo P, Benchimo C, Lopes D, Bernardino L, E do Rosário V, Varandas L \& Nogueira F (2008) Prevalence of pfmdr1, pfcrt, pfdhfr and pfdhps mutations associated with drug resistance, in Luanda, Angola. Malaria Journal. 7:236 .

18. Lynch C, Pearce R, Pota H, Cox J, Abeku TA, Rwakimari J, Naidoo I, Tibenderana J \& Roper C (2008) Emergence of a dhfr Mutation Conferring High-Level Drug Resistance in Plasmodium falciparum Populations from Southwest Uganda. The Journal of Infectious Diseases. 97:1598-604

19. Mkulama MAP, Chishimba S, Sikalima J, Rouse P, Thuma PE \& Mharakurwa S (2008) Escalating Plasmodium falciparum antifolate drug resistance mutations in Macha, rural Zambia. Malaria Journal. 7:87.

20. WHO (2009) Report of Technical Consultation: Defining and validating a measure of parasite resistance to sulfadoxinepyrimethamine (SP) that would be indicative of the protective efficacy of
$\mathrm{SP}$ for intermittent preventive treatment in infancy (SP-IPTi), Geneva, WHO.

21. Departemen Kesehatan RI (1999) Modul penemuan penderita dan pengobatan malaria. Direktorat Jenderal PPM dan PLP. Jakarta. DepKes RI.

22. Dinas Kesehatan Kabupaten Banjar (2009) Profil Kesehatan Kabupaten Banjar tahun 2008. Banjar Baru, Dinkes Kabupaten Banjar.

23. WHO Regional office for South East-Asia (WHO-SEARO) (2009) Reported malaria morbidity rate (API/1000) in Indonesia 20002008. http://www.searo.who.int/LinkFiles/ Malaria_in_the_SEAR_mr-ino.pdf (accessed on January, 19, 2010)

24. Marwoto H (2002). Resistensi P. falciparum terhadap pyrimethamine dan fansidar di Indonesia (www.litbang.depkes.go.id/jkpkbppkgdl-res-1982-harijani-611-pyrimetham (accessed on October 12, 2009)

25. Azlin E (2003) Uji klinis Acak Ganda Gabungan Sulfadoksin-Pirimetamin dengan Klorokuin pada malaria falciparum. Tesis, Universitas Sumatera Utara, Indonesia.

26. Syafruddin D, Asih PBS, Casey GJ, Maguire J, Baird K \& Nagesha HS (2005) Moleculer epidemiology of Plasmodium falciparum resistance to antimalarial drugs in Indonesia. Am. J. Trop. Med. Hyg. 72(2) : 174-181

27. Mugittu K, Ndejembi M., Malisa A., Lemnge M, Premji Z, Mwita A, Nkya W, Kataraihya J, Abdulla S, Beck HP \& Mshinda H (2004) Therapeutic Efficacy of SulfadoxinePyrimethamine and Prevalence of Resistance Markers in Tanzania Prior to Revision of Malaria treatment Policy: Plasmodium falciparum Dihydrofolate Reductase and Dihydropteroate Synthase Mutations in monitoring in vivo resistance. Am. J. Trop. Med. Hyg. 71(6):696-702

28. Griffin JT., Cairns M, Ghani AC., Roper C, Schellenberg D, Carneiro I, Newman RD., Grobusch MP, Greenwood B, Chandramohan D \& Gosling RD (2010) Protective Efficacy of Intermittent Preventive Treatment of Malaria in Infants (IPTi) Using Sulfadoxine- Pyrimethamine and Parasite Resistance. PLoS ONE. 5:9.

29. Bertin G, Briand V, Bonaventure D, Carrieu A, Massougbodji A, Cot M \& Deloron P (2011) Molecular markers of resistance to sulphadoxinepyrimethamine during intermittent preventive treatment of pregnant women in Benin. Malaria Journal.10:196

30. WHO (2010) WHO Policy recommendation on Intermittent Preventive Treatment during infancywith sulphadoxine-pyrimethamine (SPIPTi) for Plasmodium falciparum malaria control in Africa. Geneva.

31. Duraisingh MT, Curtis J \& Warhurst DC (1998) Plasmodium falciparum: Detection of Polymorphisms in the Dihydrofolate Reductase and Dihydropteroate Synthetase Genes by PCR 
and Restriction Digestion. Experimental parasitology. $89: 1-8$

32. Tinto H, Ouedraogo JB, Zongo I, Overmeir CV, Marck EV, Guiguemde TR, \& D'Alessandro U (2007) Sulfadoxine-Pyrimethamine efficacy and selection of Plasmodium falciparum DHFR mutations in Burkina Faso before its introduction as intermitten preventive treatment for pregnant women. Am. J. Trop. Med. Hyg.76(4): 608-613

33. Mbugi EV, Mutayoba BM, Malisa AL, Balthazary ST, Nyambo TB \& Mshinda H (2006) Drug resistance to sulphadoxine-pyrimethamine in Plasmodium falciparum malaria in Mlimba, Tanzania. Malaria Journal. 5:94

34. Talisuna AO, Okello PE, Erhart A, Coosemans M \& D'Alessandro U (2007) Intensity of Malaria Transmission and the Spread of Plasmodium falciparum-Resistant Malaria: A Review of Epidemiologic Field Evidence. Am. J. Trop. Med. Hyg. 77(6) : 170-180

35. Ibrahim ML, Gay-Andrieu F, Adehossi E, Lacroix V, Randrianarivelojosia M \& Duchemin JB (2007) Field-based evidence for the linkage of pfcrt and pfdhfr drug-resistant malaria genotypes and clinical profiles of severe malaria in Niger. Microbes and Infection. 9: 599-604

36. Riyanto S (2008) Faktor resiko terjadinya infeksi malaria pada ibu hamil di daerah endemis malaria di Kecamatan Sei Pinang Kabupaten Banjar. Tesis, Universitas Airlangga Surabaya, Indonesia.

37. Syafruddin D, Asih PBS, Aggarwal SL \& Shankar AH (2003) Frequency Distribution of antimalarial drug resistant alleles among isolates of Plasmodium falciparum in Purworejo District, Central Java Province, Indonesia. Am. J. Trop. Med. Hyg. 69(6): 614-620

38. Schoepflin S, Marfurt J, Goroti M, Baisor M, Mueller I \& Felger I (2008) Heterogeneous distribution of Plasmodium falciparum drug resistance haplotypes in subsets of the host population. Malaria Journal7:78

39. Almeida A, Arez AP, Cravo PVL \& Rosário VE (2009) Analysis of genetic mutations associated with anti-malarial drug resistance in Plasmodium falciparum from the Democratic Republic of East Timor. Malaria Journal. http:// www.malariajournal.com/content/8/1/59

40. Asih PBS, Rogers WO, Susanti AI, Rahmat A, Rozi1 IE, Kusumaningtyas MA, Krisin, Sekartuti, Dewi RM, Coutrier FN, Sutamihardja A, Andre JAM V, Sauerwein RW \& Syafruddin D (2009) Seasonal distribution of anti-malarial drug resistance alleles on the island of Sumba, Indonesia. Malaria Journal. http:// www.malariajournal.com / content/8/1/222

41. Marfurt J, Müller I, Sie A, Oa O, Reeder JC, Smith TA, Beck HP \& Genton B (2008) The usefulness of twenty-four molecular markers in predicting treatment outcome with combination therapy of amodiaquine plus sulphadoxinepyrimethamine against falciparum malaria in Papua New Guinea. Malaria Journal. 7:61.

42. Mita $T$ (2009) Origins and spread of pfdhfr mutant alleles in Plasmodium falciparum. Acta Tropica. Doi: 10.1016/j.actatropica.2009.07.008 